\title{
Efektifitas Undang-Undang Keistimewaan Daerah Istimewa Yogyakarta (DIY)
}

\author{
Ratna Dewi ${ }^{\star 1}$, Eko Nuriyatman² \\ ${ }^{1}$ Fakultas Hukum Universitas Jambi \\ Mendalo Darat, Jambi Luar Kota, Kota Jambi, Jambi 36122 Indonesia \\ ${ }^{2}$ Prodi Ilmu Pemerintahan Fisipol Universitas Jambi \\ Mendalo Darat, Jambi Luar Kota, Kota Jambi, Jambi 36122 Indonesia
}

\begin{abstract}
Abstrak
Tujuan penelitian ini menjelaskan efektifitas kewenangan DIY berdasarkan UndangUndang Keistimewaan. Pendekatan penelitian ini dilakukan secara kualitatif yang menghasilkan data deskriptif, yaitu data dari responden secara tertulis atau lisan dan perilaku nyata. Berdasarkan hasil penelitian dapat dijelaskan setiap kebijakan yang dibuat oleh Sri Sultan hanya akan menjadi catatan-catatan elit, jika tidak diimplementasikan oleh badan-badan administrasi maupun agen-agen pemerintah di tingkat bawah. Implementasi desentralisasi asimetris di DIY belum terlaksana secara maksimal dikarenakan masih terdapat beberapa amanat UUK DIY yang belum diterapkan dalam hal: Pertama, dalam hal penyerapan dana keistimewaan, belum diimplementasikan dengan baik dikarenakan penyaluran anggaran pada tingkat Kuasa Pengguna Anggaran (KPA) berefek pada keterlambatan transfer anggaran dan mundurnya agenda-agenda yang telah direncanakan oleh masing-masing KPA. Kedua, dalam hal kebudayaan belumlah optimal dikarenakan Pemerintah DIY dan pihak Dewan Perwakilan Rakyat Daerah (DPRD) belum menyelesaikan Perdais tentang Kebudayaan.Kesimpulan penelitian ini bahwa Pasal 7 Ayat (2) Undang-Undang Keistimewaan DIY mengenai 5 (lima) kewenangan belum dilakukan secara maksimal, karena baru dapat diselesaikan tiga Perdais tentang pengisian jabatan gubernur dan wakil gubernur DIY, tentang rencana tata ruang wilayah dan tentang kelembagaan. Namun, pada saat penelitianini dilakukan ada 2 (dua) Raperdais yang belum selesai, yaitu tentang kebudayaan dan pertanahan.
\end{abstract}

\section{Kata Kunci: Efektifitas, Undang-Undang Keistimewaan}

\begin{abstract}
The purpose of this study explains the effectiveness of the authority of DIY based on the Privileged Act. This research approach is conducted qualitatively which produce descriptive data, that is data from respondent in written or oral and real behavior. Based on the results of the research can be explained every policy made by Sri Sultan will only be the records of the elite, if not implemented by the administrative agencies and government agencies at the lower level. Implementation of asymmetric decentralization in DIY has not been implemented maximally because there are still some DIY DIY mandates that have not been implemented in terms of: Firstly, in the absorption of privileged funds, it has not been implemented properly because the budget disbursement
\end{abstract}

"PenulisKorespondensi

E-mail: dratna379@yahoo.com 
at the level of Budget User Authority (KPA) has effect on the delay of budget transfers and the withdrawal of the agenda planned by each KPA. Secondly, in terms of culture has not been optimal because the DIY Government and the Regional House of Representatives (DPRD) has not completed the Perdais on Culture. The conclusion of this study is that Article 7 Paragraph (2) of the Privilege Act of DIY concerning 5 (five) authorities has not been done maximally, since only three Perdais can be completed on the position of governor and deputy governor of DIY concerning spatial planning and institutionalization. However, at the time of this research there were 2 (two) Raperdais unfinished, that is about culture and land.

\section{Keywords: Effectiveness, Privileged Act}

\section{Pendahuluan}

Pemerintah lokal/daerah berasal dari perkembangan praktik pemerintahan di Eropa pada abad ke-11 dan 12. Pada saat itu, muncul satuan-satuan wilayah di tingkat dasar yang secara alamiah membentuk suatu lembaga pemerintah. Pada awalnya satuan-satuan wilayah tersebut merupakan suatu komunitas swakelola dari sekelompok penduduk. Satuansatuan wilayah tersebut diberi nama municipal (kota) county (kabupaten) dan commune gamentee (desa). Fenomena ini mirip dengan "satuan komunitas asli penduduk Indonesia yang disebut dengan desa (Jawa), nagari (Sumatra Barat), huta (Sumatera Utara), marga (Sumatera Selatan), gampong (Aceh) dan Kampung (Kalimantan Timur)."1

Untuk menjaga eksistensi dan kelangsungan hidupnya mereka membuat lembaga yang diperlukan. Lembaga yang dibentuk mencakup "lembaga politik, ekonomi, sosial, budaya dan pertahanan keamanan". ${ }^{2}$ Menurut Stoker "munculnya pemerintah daerah moderen berkaitan erat dengan fenomena industrialisasi
Inggris pada pertengahan abad ke-18". ${ }^{3} \mathrm{Hal}$ ini menyebabkan perpindahan penduduk dari desa ke kota secara besar-besaran yang menyebabkan berubahnya corak wilayah dan munculnya daerah-daerah baru dipinggiran kota.

Pemerintah lokal/daerah pada konteks Indonesia telah mengalami beberapa kali perubahan, terutama isu pembagian kewenangan antara pusat dan daerah. Sebelum tahun 1998,kekuasaan pemerintah pusat di Indonesia sangat sentralistik, daerah hanya menjadi perpanjangan tangan kekuasaan. Dengan kata lain, "rezim yang berkuasa saat itu,orde baru (orba) mewujudkan kekuasaan sentripetal, yakni memihak pusat bukan pinggiran (daerah)". ${ }^{4}$

B.J. Habibie yang menggantikan Soeharto sebagai presiden pasca orba membuat kebijakan politik baru dengan mengubah hubungan kekuasaan pusat dan daerah melalui Undang-Undang Nomor 5 Tahun 1999 tentang Pemerintahan Daerah. Sebelum berlakunya Undang-Undang Nomor 5 Tahun 1999, daerah hlm.1.

${ }^{1}$ Hanif Nurcholis, Teori dan Praktik Pemerintahan dan Otonomi Daerah, (Jakarta: PT Grasindo, 2005),

${ }^{2}$ Ibid.

${ }^{3} / \mathrm{bid}, \mathrm{hlm} .2$.

${ }^{4}$ Michael Malley, Daerah, Sentralisasi dan Perlawanan dalam Donald K. Emmerson, Indonesia Beyond Soeharto: Negara, Ekonomi, Masyarakat, Transisi, (Jakarta: PT Gramedia, 2001), hlm. 122. 
tidak ingin bergantung pada pusat dan tidak ingin didikte. Bahkan, beberapa daerah, seperti Aceh, Riau, Papua menuntut merdeka dan ingin berpisah dari Republik Indonesia. ${ }^{5}$

Setelah itu, berkembanglah pemerintahan daerah, seperti sekarang dengan konsep dasar sebagai berikut:

1. Sentralisasi;

2. Desentralisasi; dan

3. Dekonsentrasi.

Menurut Pasal 18 Ayat (1) UndangUndang Dasar Negara Republik Indonesia Tahun 1945 ditentukan bahwa "Negara Kesatuan Republik Indonesia (NKRI) dibagi atas daerah-daerah provinsi dan daerah provinsi itu dibagi atas kabupaten dan kota, yang tiap-tiap provinsi, kabupaten dan kota itu mempunyai pemerintahan daerah yang diatur dengan undang-undang". Pemerintah daerah provinsi, daerah kabupaten dan kota mengatur dan mengurus sendiri urusan pemerintahan menurut asas otonomi dan tugas pembantuan.

Sebagaimana telah disinggung pemerintah lokal/daerah telah mengalami perubahan dan perkembangan yang dinamis. Peraturan perundang-undangan tentang pemerintahan daerah telah mengalami perubahan sebanyak 8 (delapan) kali. Perubahan itu dimulai dari Undang-Undang Nomor 1 Tahun 1945 tentang Pemerintahan Daerah sampai terakhir, yaitu Undang-Undang Nomor 23 Tahun 2014 tentang Pemerintahan Daerah.

Menurut Pasal 1 Ayat (6) Undang-Undang Nomor 23 Tahun 2014 mendefenisikan "otonomi daerah adalah hak, wewenang dan kewajiban daerah otonom untuk mengatur dan mengurus sendiri urusan pemerintahan dan kepentingan masyarakat setempat dalam sistem NKRI".

Pola hubungan kekuasaan dalam sistem NKRI sangat bergantung pada konfigurasi politik pada saat itu. Termasuk pola pembagian kewenangan dan perimbangan keuangan yang mempengaruhi formalitas penyelenggaraan pemerintahan daerah dan pemberian otonomi daerah. Bagir Manan berpendapat "dalam tataran pelaksanaan, belum pernah otonomi dijalankan semestinya. Pemerintahan pusat gamang dan tidak tulus merumuskan dan menjalankan arti otonomi dengan berbagai alasan pembenaran". ${ }^{6}$ Semestinya dalam NKRI pembagian urusan pusat dan daerah mengacu pada pola desentralisasi. Pembagian urusan pemerintahan tersebut dibedakan menjadi 3 (tiga) bagian, yaitu

1. Urusan pemerintah absolut;

2. Urusan pemerintah konkuren; dan

3. Urusan pemerintah umum.

Perubahan kebijakan hubungan pusat dan daerah di Indonesia pada dasarnya mengacu pada "ultra vires doctrinal (merinci satu persatuan urusan pemerintah yang diberikan kepada daerah) dan risidual power atau open and arregement (konsep kekuasaan asli atau kekuasaan sisa)". ${ }^{7}$ Ultra vires doctrinal lebih pada sentralisasi, sedangkan risidual power lebih mengarah pada desentralisasi. Dalam tata pemerintahan di Indonesia, dikenal dua bentuk desentralisasi, yaitu desentralisasi simetris dan desentralisasi asimetris. Desentralisasi simetris berpedoman pada Undang-Undang Nomor 23 Tahun 2014 tentang Pemerintahan Daerah, sedangkan desentralisasi asimetris

${ }^{5}$ Budi Agustono, Otonomi Daerah dan Dinamika Politik Lokal: Studi Kasus di Kabupaten Deli Serdang, Sumatera Utara dalam Desentralisasi Globalisasi dan Demokrasi Lokal, (Jakarta: LP3ES, 2005),hlm. 163. hlm. 27.

${ }^{6}$ Bagir Manan, Menyongsong Fajar Otonomi Daerah, (Yogyakarta: Pusat Studi Hukum UII, 2004),

${ }^{7}$ Hanif, Teori dan Praktek Pemerintahan, (Jogjakarta: Grafindo, 2003), hlm. 6. 
adalah konsep desentralisasi yang mengakui keistimewaan, otonomi khusus dan kekhususan suatu daerah.

Saat berlakunya Undang-Undang Nomor 22 Tahun 1999 lebih bernuansa desentralisasi asimetris, didalamnya ada pemberian otonomi khusus bagi beberapa daerah. Sementara, dalam Undang-Undang Nomor 5 Tahun 1974 hanya desentralisasi simetris (biasa). Secara etimologis, istilah "desentralisasi berasal dari bahasa Latin, 'de' berarti lepas dan 'centrum' berarti pusat. Oleh karena itu, dari pengertian asal katanya desentralisasi berarti melepaskan

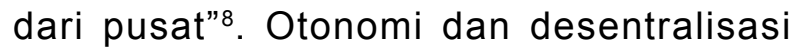
menegaskan bahwa terdapat dua elemen pengertian pokok, yaitu pembentukan daerah otonom dan penyerahan kekuasaan secara hukum untuk menangani bidang-bidang pemerintahan tertentu, baik yang dirinci maupun yang dirumuskan secara umum.

Philip Mawhod mengartikan desentralisasi adalah "pembagian dari sebagian kekuasaan pemerintah oleh kelompok yang berkuasa di pusat terhadap kelompok-kelompok lain yang masing-masing memiliki otoritas di dalam wilayah tertentu di suatu negara". ${ }^{9}$ Sementara itu, Irawan Soejito mendefinisikan "desentralisasi memiliki arti sebagai pelimpahan wewenang pemerintahan untuk dilaksanakan". ${ }^{10}$ Melalui sudut leksikografi, desentralisasi adalah "pembalikan dari konsentrasi administrasi pada satu pusat dan sekaligus pemberian kekuasaan kepada daerah". ${ }^{11}$
Isharyanto menulis dalam akun blognya mengenai desentralisasi, yaitu "desentralisasi asimetris (asymmetric decentralization) bukanlah pelimpahan kewenangan biasa. la berbentuk pelimpahan kewenangan khusus yang hanya diberikan kepada daerah-daerah tertentu. Secara empirik, ia merupakan strategi komprehensif pemerintah pusat guna merangkul kembali daerah yang hendak memisahkan diri dari ibu pertiwi. Melalui kebijakan desentralisasi asimetris diakomodasi tuntutan dan identitas lokal ke dalam suatu sistem pemerintahan lokal yang khas". ${ }^{12}$

Contoh pemerintahan lokal yang khas, yaitu Daerah Istimewa Yogyakarta (DIY). Pemerintah DIY menerbitkan Peraturan Daerah Nomor 1 Tahun 2013 tentang Tata Cara Pembentukan Pembentukan Peraturan Daerah Istimewa. DIY memiliki keistimewaan dalam kedudukan hukum berdasarkan sejarah dan hak asal-usul menurut Undang-Undang Dasar Negara Kesatuan Republik Tahun 1945 untuk mengatur dan mengurus kewenangan istimewa.

Pemahaman umum tentang definisi dan ruang lingkup desentralisasi selama ini banyak mengacu kepada Bank Dunia (World Bank, 2001), yaitu "Desentralisasi adalah transfer kewenangan dan tanggung jawab fungsi-fungsi pemerintahan dari pemerintah pusat kepada pemerintah daerah, lembaga semi-pemerintah, maupun kepada swasta desentralisasi sendiri terdiri dari empat jenis, yakni desentralisasi

${ }^{8}$ Dharma Setyawan Salam, Otonomi Daerah Dalam Perspektif Lingkungan, Nilai, dan Sumber Daya, (Jakarta: Djambatan, 2002), hlm. 74.

${ }^{9}$ Siswanto Sunarno, Hukum Pemerintahan Daerah di Indonesia, (Jakarta: Sinar Grafika, 2006), hlm. 13. hlm. 20.

${ }^{10}$ Irawan Soejito, Hubungan Pemerintah Pusat dan Pemerintah Daerah, (Jakarta: Bina Aksara, 1984),

${ }^{11}$ Syamsuddin Haris, Desentralisasi dan Otonomi Daerah: Desentralisasi, Demokratisasi dan Akuntabilitas Pemerintahan Daerah, (Jakarta: LIPI Press, 2005), hlm. 40.

${ }^{12}$ /sharyanto.wordpress.com/denyut-otonomi/desentralisasi-asimetris-peluang-atau -keti-adagunaan, diakses pada tanggal 06 November 2015. 
politik, desentralisasi administratif, desentralisasi fiskal, serta desentralisasi pasar". ${ }^{13}$

Berdasarkan sisi kemanfaatan, desentralisasi lebih tepat meningkatkan efisiensi dan daya tanggap pemerintah melalui pemenuhan layanan publik yang lebih sesuai dengan preferensi rakyat. Dari hasil kajian dan penelitian menemukan bukti bahwa desentralisasi berhasil mendorong terwujudnya tiga kondisi penting, yaitu ${ }^{14}$

1. Meningkatnya kepedulian dan penghargaan terhadap partisipasi masyarakat dalam proses politik di tingkat lokal.

2. Perangkat pemerintahan daerah memiliki komitmen yang makin kuat dalam pemberian layanan serta merasakan adanya tekanan yang berat dari masyarakat agar mereka meningkatkan kualitas pelayanan publik.

3. Pemerintah daerah saling bekerjasama dan berbagi informasi untuk menyelesaikan persoalan yang samasama mereka hadapi. Walaupun demikian, beberapa dampak negatif nampaknya tidak dapat dihindari.

Meskipun memiliki dua sisi yang berbeda (manfaat dan kelemahan), namun terdapat sebuah kesepakatan umum bahwa desentralisasi sangat diperlukan untuk mempromosikan sosok pemerintahan yang lebih baik, lebih efektif dan lebih demokratis (good governance). Tata pemerintahan bukan hanya dalam pengertian struktur dan manajemen lembaga yang disebut eksekutif, karena pemerintah (goverment) hanyalah salah satu dari tiga aktor besar yang membentuk lembaga yang disebut governance. Dua aktor lain, yaitu "private sector (sektor swasta) dan civil society (masyarakat)". ${ }^{15}$

Memahami governance merupakan bentuk pemahaman tentang integrasi peran antara pemerintah (birokrasi), sektor swasta dan masyarakat dalam suatu aturan main yang disepakati bersama. Lembaga pemerintah harus mampu menciptakan lingkungan ekonomi, politik, sosial budaya, hukum dan keamanan yang kondusif. United Nations Development Program (UNDP) mendifinisikan good governance sebagai hubungan yang sinergis dan konstruktif di antara negara, sektor swasta dan masyarakat. Berdasarkan definisi tersebut, UNDP kemudian mengajukan karakteristik good governance yang saling memperkuat dan tidak dapat berdiri sendiri, sebagai berikut. ${ }^{16}$

1. Participation, bahwa setiap warga negara mempunyai suara dalam pembuatan keputusan.

2. Rule of law, berarti kerangka hukum harus adil dan dilaksanakan tanpa perbedaan, terutama dalam hukum dan Hak Asasi Manusia (HAM).

3. Transparency, kebebasan arus informasi.

\footnotetext{
${ }^{13}$ World Bank, "Decentralization and Governance: Does Decentralization Improve Public Service Delivery" in Prem-Notes No. 55,diakses dari: http://hazni.blog.esaunggul.ac.id, diakses pada tanggal 27 November 2014.

${ }^{14}$ IRDA, Decentralization and Local Governance in Indonesia: First and Second Report on the Indonesian Rapid Decentralization Appraisal (IRDA), Jakarta: Asia Foundation, diakses dari: http:// hazni.blog.esaunggul.ac.id, pada tanggal 27 November 2014.

${ }^{15} \mathrm{Ibid}$, hlm. 5.

${ }^{16}$ Sedarmayanti, Good Governance (Kepemerintahan yang Baik), Cetakan Kedua,(Bandung: Mandar Maju, 2004), hlm. 8.
} 
4. Responsiveness, pertanggungjawaban.

5. Consensus orientation, good governance menjadi perantara kepentingan yang berbeda untuk memperoleh pilihan yang terbaik bagi kepentingan yang lebih luas.

6. Effectiveness and efficiency.

7. Accountability.

8. Strategic vision.

Politik hukum tentang desentralisasi yang digariskan Undang-Undang Dasar Negara Republik Indonesia Tahun 1945 mengisyaratkan: Pertama, pengembangan desentralisasi asimetris yang menekankan kekhususan, keistimewaan, keberagaman daerah, serta kesatuan-kesatuan masyarakat hukum adat dan hak-hak tradisional. Kedua, pengembangan desentralisasi asimetris dimaksud diatur lebih lanjut dengan undang-undang. Hingga saat ini terdapat 4 (empat) undang-undang yang mengatur secara khusus, yakni

1. Undang-Undang Nomor 13 Tahun 2012 tentang Keistimewaan Daerah Istimewa Yogyakarta.

2. Undang-Undang Nomor 29 Tahun 2007 tentang Pemerintah Provinsi Daerah Khusus Ibukota Jakarta sebagai Ibukota Negara Kesatuan Republik Indonesia.

3. Undang-Undang Nomor 11 Tahun 2006 tentang Pemerintahan Aceh.

4. Undang-Undang Nomor 21 Tahun 2001 tentang Otonomi Khusus Provinsi Papua.

Undang-Undang Dasar Negara Republik Indonesia Tahun 1945 menganut model desentralisasi simetris (seragam) dan mengakui pula desentralisasi asimetris (beragam). Pengaturan tentang desentralisasi asimetris ditemukan dalam Pasal 18AAyat (1), Pasal 18B
Ayat (1) dan (2). Pasal 18A Ayat (1) mengamanatkan "hubungan wewenang antara pemerintah pusat dan pemerintahan daerah provinsi, kabupaten dan kota, diatur dengan undang-undang dengan memperhatikan kekhususan dan keragaman daerah".

Berbicara mengenai asas desentralisasi maka setidaknya ada empat faktor yang relevan mengenai desentralisasi, yaitu

1. Rezim pemerintah yang berkuasa.

2. Situasi dan kondisi.

3. Aspirasi apa yang berkembang dalam masyarakat di daerah sangat dominan.

4. Kearifan lokal yang tidak dapat diingkari sebagai suatu realita sosial budaya bangsa.

Dari berbagai isu asas desentralisasi, otonomi daerah, dan otonomi khusus, seperti di Provinsi Nanggroe Aceh Darusalam (NAD), Papua/Papua Barat, serta keistimewaan DIY menimbulkan polemik wacana tentang konsep antara sentralisasi, desentralisasi simetris dan desentralisasi asimetris.

Agus Dwiyanto menyebutkan ada tiga penyebab kebijakan otonomi daerah harus dikaji ulang, yaitu "melihat besarnya keragaman antar daerah, pilihan kebijakan desentralisasi seragam yang telah dilaksanakan selama satu dekade terakhir perlu ditinjau kembali. Pertama, model desentralisasi seragam dalam keanekaragaman daerah bertentangan dengan hukum alam dan nilai yang terkandung dalam desentralisasi itu sendiri. Kedua, desentralisasi seragam mengabaikan kenyataan bahwa daerah memiliki tingkat kematangan, cakupan wilayah, potensi daerah, dan jumlah penduduk yang berbeda antara satu dengan lainnya. Ketiga, model desentralisasi seragam yang sekarang berlaku mempersulit daerah dalam pengembangan struktur birokrasi yang efisien dan aparatur yang profesional, mengingat 
kompetensi dan kebutuhan mereka berbedabeda. ${ }^{17}$

Perlu disadari, dipahami dan digarisbawahi, pada dasarnya secara filosofis asas sistem pemerintahan daerah apapun, baik itu sentralisasi, desentralisasi simetris maupun desentralisasi asimetris pada akhirnya untuk kesejahteraan rakyat. Asas desentralisasi dalam pemerintahan daerah urgen dan krusial untuk dianalisis dan selanjutnya diimplementasikan sebagai suatu kebijakan dalam penyelenggaraan pemerintahan daerah dengan tetap berprinsip menjaga persatuan dan kesatuan dalam wadah NKRI.

Ada beberapa alasan mengapa kebutuhan terhadap desentralisasi di Indonesia dirasakan sangat mendesak. Pertama, kehidupan berbangsa dan bernegara selama ini sangat terpusat di Jakarta (Jakarta sentris). Sementara itu, pembangunan dibeberapa wilayah dilalaikan. Kedua, pembagian kekayaan tidak adil dan merata. Daerah yang memiliki sumber kekayaan alam melimpah, seperti Aceh, Riau, Irian Jaya (Papua), Kalimantan, dan Sulawesi ternyata tidak menerima perolehan dana yang patut dari pusat. Ketiga, kesenjangan sosial (dalam makna seluas-luasnya) antara satu daerah dengan daerah lain sangat terasa. Pembangunan fisik di satu daerah berkembang pesat, sedangkan daerah lain justru lamban dan bahkan terbengkalai. ${ }^{18}$

Secara teoritis maupun empiris penyelenggaraan sistem pemerintahan daerah sejak dahulu hingga sekarang seringkali diposisikan pada pilihan alternatif yang sulit dalam penerapan asas desentralisasi. Sangat logis dan sudah waktunya untuk mulai merumuskan dan menetapkan kebijakan desentralisasi asimetris.

Djohermansyah Djohan menjelaskan "desentralisasi asimetris (asymetric decentrlization) bukanlah pelimpahan kewenangan khusus yang hanya diberikan kepada daerahdaerah tertentu. Secara empirik ia merupakan strategi komprehensif pemerintah pusat guna merangkul kembali daerah yang hendak memisahkan diri dari ibu pertiwi. Melalui kebijakan desentralisasi asimetris mengakomodasi tuntutan identitas lokal ke dalam suatu sistem pemerintahan lokal yang khas. ${ }^{19}$

Sebagaimana disinggung DIY merupakan contoh pemerintahan lokal yang khas. Undang-Undang Nomor 13 Tahun 2012 tentang Keistimewaan Daerah Istimewa Yogyakarta menyebutkan status istimewa yang melekat pada DIY merupakan bagian integral dalam sejarah pendirian negara-bangsa Indonesia. Kewenangan keistimewaan meliputi tata cara pengisian jabatan, kedudukan, tugas dan wewenang Gubernur dan Wakil Gubernur, kelembagaan pemerintah DIY, kebudayaan, ketahanan dan tata ruang. Dengan demikian, pemerintah DIY mempunyai kewenangan yang meliputi kewenangan istimewa berdasarkan undang-undang ini dan undang-undang pemerintah daerah.

Undang-Undang Nomor 13 Tahun 2013 tentang Keistimewaan Daerah Istimewa Yogyakarta, terdiri dari 16 bab dan 51 pasal,

${ }^{17}$ Wahyudi Kumorotomo dan Ambar Widaningrum, Reformasi Aparatur Negara Ditinjau Kembali, (Yogyakarta: Gava Media, 2010), hlm. 188-189.

${ }^{18}$ Tim ICCE UIN Jakarta, Pendidikan Kewargaan (Civic Education) Demokrasi,Hak Asasi Manusia dan Masyarakat Madani, (Jakarta: Prenada Media, 2003), hlm. 152-153. 2014.

${ }^{19}$ Djohermansyah Djohan, Desentralisasi Asimetris Aceh, Jurnal Sekretariat RI, Nomor 15, Desember 
terbagi atas 5 (lima) aspek dan ruang lingkup kewenangansebagai berikut:

1. Tata cara pengisian jabatan, kedudukan, tugas dan wewenang gubernur dan wakil gubernur;

2. Kelembagaan pemerintah DIY;

3. Kebudayaan;

4. Pertanahan; dan

5. Tata ruang.

Ada 3 (tiga) elemen yang melekat pada keistimewaan DIY terkait aspek budaya, yaitu ${ }^{20}$

1. Kraton sebagai institusi adat yang melukiskan karya adiluhur (court cultura).

2. Unsur transformasi nilai-nilai modernitas melalui jalur pendidikan.

3. Fungsi sultan sebagai mediator kosmologis antara misi kerajaan Islam dengan realitas masyarakat yang pluralis.

Faktor kebudayaan merupakan suatu kewenangan yang dimiliki oleh DIY. Daerah ini setingkat provinsi dikepalai oleh Sri Sultan Hamengkubuwono $X$ sebagai kepala DIY dan Sri Paku Alam IX sebagai wakil kepala DIY. Provinsi DIY dibentuk berdasarkan UndangUndang Dasar Negara Kesatuan Republik Indonesia Tahun 1945 dengan dikeluarkannya amanat kedua 30 Oktober 1945. Berdasarkan amanat tersebut telah dibentuk suatu badan pekerja yang bertugas menjalani fungsi legislatif di wilayah DIY. Melalui tata pemerintahan seperti ini, semua dekrit yang dikeluarkan oleh Kesultanan dan Paku Alam ditandatangani oleh badan pekerja sebagai wakil atas nama rakyat. Bentuk pemerintahan DIY berdasarkan pengamatan dan pemahaman penulis mempunyai dua bentuk, yaitu

1. Bentuk pemerintahan kerajaan sesuai dengan kebudayaan lokal.

2. Bentuk pemerintahan sesuai dengan pemerintahan yang moderen.

Terkait keistimewaan DIY, dalam penyelenggaraan pemerintahannya sebaiknya tetap memperhatikan hal-hal yang rasional dalam membuat kebijakan. Kebijakan rasional menurut Jamal Wiwoho sebagai berikut. ${ }^{21}$

1. Mengetahui semua nilai-nilai utama yang ada dalam masyarakat.

2. Mengetahui semua alternatif kebijakan yang tersedia.

3. Mengetahui semua konsekuensi dari setiap alternatif kebijakan.

4. Mengetahui rasio antara tujuan dan nilai-nilai sosial yang dikorbankan bagi setiap alternatif kebijakan. dan

5. Memilih alternatif kebijakan yang paling efisien.

Proses pembuatan kebijakan dan penilaian terhadap aspek-aspek yang rasional tentulah melahirkan kebijakan yang tidak semata berpihak pada kepentingan penguasa. Dalampenyelenggaraan pemerintahan daerah, kebijakanpublik dan hukum mempunyai peranan penting. Terkait hukum meliputi dua aspek, yaitu $^{22}$

1. Aspek keadilan, menyangkut kebutuhan dan rasa adil dari sekian banyak dinamika dan konflik di masyarakat.

\footnotetext{
${ }^{20}$ Jawahir Thontowi, Apa Istimewa Yogyakarta?, (Yogyakarta: Pustaka Fahim, 2007), hlm. 7.

${ }^{21}$ Jamal Wiwiho, Model-Model Kebijakan Publik, Surakarta, diakses dari Jamalwiwoho.com/materi-kuliah, pada tanggal 03 November 2015.

${ }^{22}$ Wibowo Eddi, Hukum dan Kebijakan Publik, (Yogyakarta: Yayasan Pembaruan Administrasi Publik Indonesia, 2004), hlm. 30-31.
} 
2. Aspek legalitas, menyangkut hukum positif, yaituaturan yang ditetapkan sah dan dalam pemberlakuannya dapat dipaksakan atas nama hukum.

Terkait keistimewaan DIY, dalam penyelenggaraan pemerintahan sebaiknya tetap memperhatikan kebijakan yang rasional. Beberapa penelitian terdahulu belum menyentuh tentang efektifitas kewenangan DIY.

Sakir dan Dyah Mutiarin meneliti kebijakan anggaran dana keistimewaan DIY, menjelaskan implementasi kebijakan anggaran dana keistimewaan sejak tahun 2013 sampai tahun 2015 masih belum maksimal. Beberapa temuannya berkaitan dengan pelaksanaan kebijakan anggaran dana keistimewaan, yaitu Pertama, prioritas dana keistimewaan. Kedua, kualitas belanja dana keistimewaan. Ketiga, kepentingan dana keistimewaan. Keempat, pemangku kepentingan dana keistimewaan. Kelima, penerima manfaat dana keistimewaan. ${ }^{23}$

Baharudin penelitiannya menganalisis mengenai pengaturan daerah khusus/istimewa dalam sistem NKRI menurut konstitusi, dan mengkaji desain ideal daerah khusus/istimewa dalam rangka memperkokoh sistem NKRI menurut Konstitusi. Hasil penelitiannya menjelaskan desain daerah khusus/istimewa diberikan bagi daerah setingkat provinsi dan daerah setingkat kabupaten/kota. Desain pemberian status kekhususan/keistimewaan dalam Negara Indonesia dilandasi berbagai alasan, mulai dari sejarah sampai dengan posisi strategis kenegaraan. Secara teoritis pembentukan otonomi khusus merupakan salah satu cara atau pilihan yang dilakukan oleh suatu negara untuk menjaga keutuhannya negara kesatuan. ${ }^{24}$

Sulianti Siti Rochmah Ika meneliti perbandingan kinerja keuangan DIY sebelum dan sesudah otonomi daerah. Penelitiannya menjelaskan tingkat efisiensi belanja daerah Provinsi DIY sebelum otonomi daerah dan sesudah otonomi daerah belum bisa dikatakan efisien. Bahkan jika dilihat rata-rata prosentase sebelum dan sesudah otonomi daerah tidak terjadi peningkatan efisiensi belanja, prosentasenya stagnan di angka lebih dari $80 \%$. Dengan menggunakan analisis time series diperkirakan efisiensi belanja daerah Provinsi DIY tidak akan mengalami peningkatan, diperkirakan beban belanja akan terus meningkat sehingga semakin sulit untuk mencapai efisiensi.

Sukirno dan Dwi Kuncahyo meneliti tentang penerapan desentralisasi asimetris dalam penyelenggaraan urusan keistimewaan DIY sebagai basis otonomi bagi terwujudnya kesejahteraan rakyat. Penelitiannya menyimpulkan kebudayaan merupakan urusan keistimewaan DIY paling potensial dapat meningkatkan kesejahteraan rakyat, karena urusan kebudayaan merupakan kegiatan yang secara langsung melibatkan semua orang. Hingga tahun ke-3 (tiga), pelaksanaan urusan keistimewaan DIY belum berjalan secara efektif dan optimal, karena terkendala keterlambatan regulasi dan keterlambatan pencairan dana keistimewaan dari Pemerintah Pusat. Penerapan desentralisasi asimetris dalam penyelenggaraan urusan keistimewaanDIY masih terkesan belum sungguh-sungguh

\footnotetext{
${ }^{23}$ Sakir dan Dyah Mutiarin, Kebijakan Anggaran Dana Keistimewaan Daerah Istimewa Yogyakara, Jurnal Ilmu Pemerintahan \& Kebijakan Publik, Volume 2, Nomor 3, Oktober 2015, hlm. 487-489.

${ }^{24}$ Baharudin, Desain Daerah Khusus/Istimewa Dalam Sistem Negara Kesatuan Republik Indonesia Menurut Konstitusi, Jurnal Masalah-Masalah Hukum, Jilid 45, Nomor 2, April 2016, hlm. 85.
} 
karena campur tangan PemerintahPusat masih sangat dominan. ${ }^{25}$

Penelitian terdahulu jelas belum menyentuh tentang efektifitas kewenangan DIY, sehingga penelitian ini berbeda dengan penelitian sebelumnya. Adapun permasalahan yang diangkat dalam penelitiannya, yaitu bagaimana efektifitas kewenangan DIY berdasarkan Undang-Undang Keistimewaan. Cara pendekatan penyelesaian masalah dilakukan secara kualitatif dengan data deskriptif yang dinyatakan responden secara tertulis atau lisan dan perilaku nyata. Hasil yang diharapkan dari penelitian ini, yaitu menjelaskan efektifitas kewenangan DIY berdasarkan Undang-Undang Keistimewaan.

\section{Metode Penelitian}

Pendekatan penelitian ini dilakukan secara kualitatif yang menghasilkan data deskriptif, yaitu datadari responden secara tertulis atau lisan dan perilaku nyata". ${ }^{26}$ Dalam penelitian kualitatif deskriptif selalu menyajikan data dan temuan dalam bentuk deskriptif kalimat yang rinci, lengkap dan mendalam mengenai proses bagaimana sesuatu terjadi.

Pendekatan kualitatif deskriptif digunakan karena akan memberikan jawaban atas permasalahan yang diteliti, sehingga memberikan jawaban penelitian nondoktrinal berawal dari data sekunder kemudian dilanjutkan kedata primer yang diperoleh langsung dari lapangan.

\section{Pembahasan}

\section{Efektifitas Kewenangan DIY Berdasarkan Undang-Undang Keistimewaan}

Undang-Undang Dasar Negara Kesatuan Republik Indonesia Tahun 1945 mengatur tentang desentralisasi dan satuan pemerintah daerah di Indonesia.Undang-Undang Dasar tersebut selain menganut sistem desentralisasi simetrias (seragam) dan mengakui pula desentralisasi asimetris (beragam). Pengaturan mengenai desentralisasi asimetris ditemukan dalam Pasal 18A Ayat (1), Pasal 18B Ayat (1) dan Ayat (2) tergambar kerangka pikir pada bagan berikut:

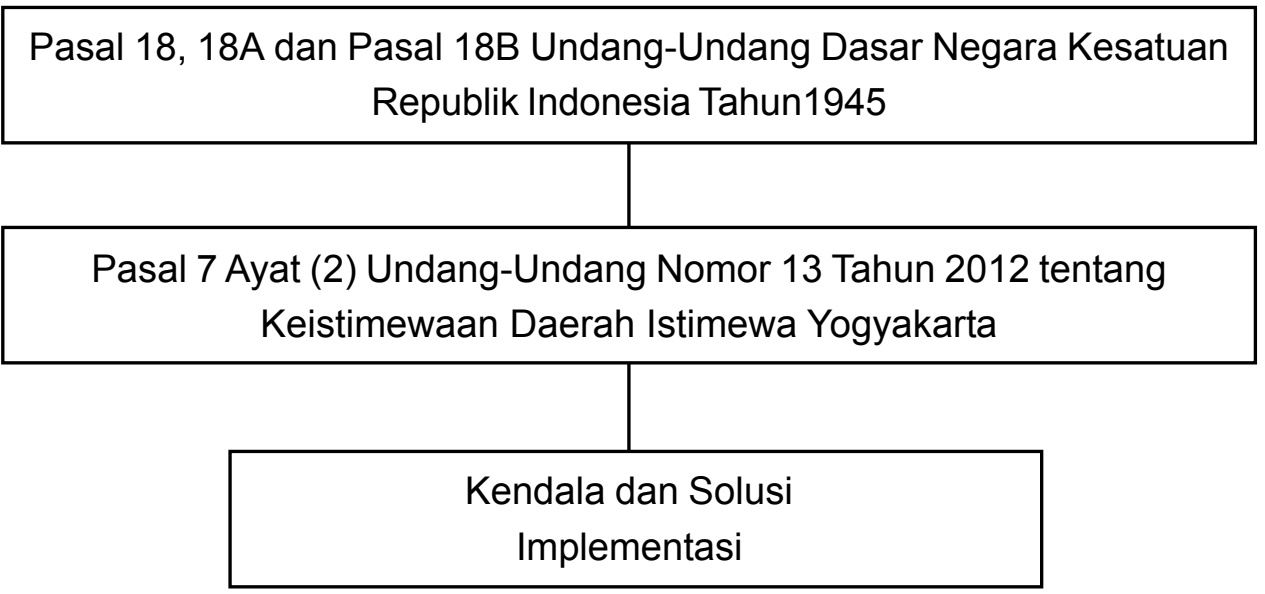

\footnotetext{
${ }^{25}$ Sukirno dan Dwi Kuncahyo, Penerapan Desentralisasi Asimetris Dalam Penyelenggaraan Urusan Keistimewaan Daerah Istimewa Yogyakarta Sebagai Basis Otonomi Bagi Terwujudnya Kesejahteraan Rakyat, Jurnal Cakrawala Hukum, Volume XI, Nomor 1, Tahun 2015, hlm. 120-121.

${ }^{26}$ Soerjono Soekamto, Faktor-Faktor yang Mempengaruhi Penegakan Hukum, (Jakarta: Rajawali Pers, 1983),hlm. 32.
} 
Politik hukum desentralisasi yang digariskan Undang-Undang Dasar Negara Kesatuan Republik Indonesia Tahun 1945 mengisyaratkan:Pertama, pengembangan desentralisasi asimetris yang menekankan kekhususan, keistimewaan, keberagaman daerah, serta kesatuan masyarakat-masyarakat hukum adat dan hak-hak tradisional. Kedua, pengembangan desentralisasi asimetris dimaksud diatur lebih lanjut dengan undang-undang.

Menurut pengamatan penulis, politik hukum desentralisasi yang digariskan UndangUndang Dasar Negara Kesatuan Republik Indonesia Tahun 1945 belum secara serius ditanggapi oleh pemerintah pusat, sehingga beberapa daerah menuntut kekhususan dan keistimewaan yang kemudian direspon dengan sejumlah undang-undang. Selanjutnya, dalam implementasi dikenal namanya kebijakan publik. "Kebijakan publik terdiri dari dua kata, yakni kebijakan dan publik, kata "kebijakan" merupakan terjemahan dari kata Inggris "policy" artinya politik, siasat dan kebijaksanaan". ${ }^{27}$ Kebijakan publik dapat diartikan sebagai tindakan yang dilakukan oleh pemerintah daerah yang mempunyai dampak terhadap banyak orang.

Pembuatan kebijakan publik di DIY harus didasarkan pada Pasal 1 Ayat (3) UndangUndang Dasar Negara Kesatuan Republik Indonesia Tahun 1945. Dengan demikian, dalam penyelenggaraan pemerintahan daerah maka tindakan yang dilakukan baik oleh pemerintah daerah maupun masyarakatnya harus didasarkan pada hukum. Dasar hukum bagi pemerintah daerah dalam melakukan tindakannya dapat dilihat dari dua sisi, yakni memberikan keabsahan bagi tindakan yang dilakukan dan memberikan perlindungan hukum jika terjadi gugatan yang dilakukan oleh masyarakatnya. Dengan demikian, hukum dapat digunakan sebagai sarana bagi kebijakan publik untuk mewujudkan tujuan yang telah ditetapkan melalui proses politik.

Hukum tertulis sebagai hukum positif merupakan hukum yang ditetapkan oleh pejabat yang berwenang. Sehubungan dengan hukum positif tersebut Pasal 7 Ayat (1) UndangUndang Nomor 12 Tahun 2011 tentang Pembentukan Peraturan Perundang-Undangan telah ditentukan hirarkinya sebagai berikut:

1. Undang-Undang Dasar Negara Kesatuan Republik Indonesia Tahun 1945;

2. Ketetapan Majelis Permusyawaratan Rakyat;

3. Undang-Undang/Peraturan Pemerintah Pengganti Undang-Undang;

4. Peraturan Pemerintah;

5. Peraturan Presiden;

6. Peraturan Daerah Provinsi; dan

7. Peraturan Daerah Kabupaten/Kota.

Khususnya DIYyang menjadi kajian penelitian ini terkait dengan implementasi efektifitas dari keistimewaannya. Setiap kebijakan yang dibuat oleh Sri Sultan hanya akan menjadi catatan-catatan elit, jika tidak diimplementasikan oleh badan-badan administrasi maupun agen-agen pemerintah di tingkat bawah.

Kebijakan yang dibuat seharusnya dilaksanakan oleh unit-unit administrasi yang memobilisasikan sumber daya finansial dan manusia. Dalam tahap implementasi kebijakan, berbagai kepentingan akan saling bersaing. Beberapa implementasi kebijakan bisa mendapat dukungan para pelaksana

\footnotetext{
${ }^{27}$ Wojowasito S, Kamus Umum Inggris-Indonesia, (Jakarta: Cypress, 1975), hlm. 60.
} 
(implementors), namun dilain pihak mungkin akan ditentang.

Kondisi geografis, budaya, tipologi ekonomi yang bervariasi antar daerah menuntut adanya strategi kebijakan agar mampu mendorong akselerasi pembangunan daerah. Sejak dimulainya reformasi dan sampai saat ini, sudah beberapakali terjadi perubahan terhadap Undang-Undang Pemerintah Daerah. Berbagai dinamika dalam perubahan kebijakan Pemerintahan Daerah tersebut mulai dari arah sentralisitik sampai desentralistik. Sebagai Negara Kesatuan Republik Indonesia tentu menerapkan pembagian urusan pusat dan daerah dengan tetap mengacu pada pola desentralisasi, dekonsentrasi dan tugas pembantuan.

Sebelum lahirnya Undang-Undang Nomor 23 Tahun 2014 tentang Pemerintahan Daerah yang berlaku Undang-Undang Nomor 32 Tahun 2004 yang mengatur hal-hal tentang pembentukan daerah dan kawasan khusus, pembagian urusan pemerintahan, penyelenggaraan pemerintahan, kepegawaian daerah, peraturan (daerah) dan peraturan kepala daerah, perencanaan pembangunan daerah, keuangan daerah, kerja sama dan penyelesaian perselisihan, kawasan perkotaan, desa, pembinaan dan pengawasan, pertimbangan dalamkebijakan otonomi daerah.

Terkait daerah yang bersifat khusus dan istimewa, dikenal beberapa bentuk pemerintahan, seperti Daerah Khusus Ibukota(DKI) Jakarta, Daerah Istimewa (DI) Nanggroe Aceh Darusalam, Otonomi Khusus Papua dan Papua Barat dan DIY. Bagi daerah-daerah ini secara prinsip tetap diberlakukan sama dengan daerahdaerah lain.
Undang-Undang Nomor 23 Tahun 2014 Juncto Undang-Undang Nomor 9 Tahun 2015 tentang Pemerintahan Daerah, masih menerapkan pola "residual power atau open arrangement (konsep kekuasaan asli atau kekuasaan sisa)", ${ }^{28}$ bahkan urusan pemerintah dibagi menjadi urusan pemerintah absolut, urusan pemerintah konkruen dan urusan pemerintahan umum (Pasal 9). Urusan pemerintah absolut adalah urusan pemerintah yang sepenuhnya menjadi kewenangan pemerintah pusat (politik luar negeri, pertahanan, keamanan, yustisi, moneter, fiskal, dan agama). Urusan pemerintah konkruen adalah urusan pemerintahan yang dibagi antara pemerintah pusat dan daerah provinsi dan daerah kabupaten/kota.

Meskipun telah berlaku selama empat tahun sejak disahkannya Undang-Undang Keistimewaan Daerah Istimewa Yogyakarta (UUK DIY), masih terdapat beberapa kendala pelaksanaan teknis. Dimulai dari masalah penyerapan anggaran, kendala waktu pencairan anggaran pusat kedaerah, penetapan gubernur dan wakil gubernur, tata ruang dan pertanahan.

DIY merupakan provinsi yang memiliki kewenangan istimewa tersendiri sejak diatur dalam Undang-Undang Nomor 3 Tahun 1950 dan saat ini telah direvisi dalam Undang-Undang Nomor 13 Tahun 2012 tentang Keistimewaan Daerah Istimewa Yogyakarta.Begitu Republik Indonesia merdeka, "Sri Sultan Hamengku Buwono IX dan Sri Paku Alam VIII menyatakan bergabung, sehingga Presiden Soekarno memberikan Piagam Kedudukan kepada mereka berdua. Sri Sultan Hamengku Buwono IX dan Sri Paku Alam VIII menyatakan tegas

${ }^{28}$ Hanif Nurcholis, Teori dan Praktek...Op.Cit., hlm. 4. 
bahwa mereka berdua Kepala Daerah di Yogyakarta". ${ }^{29}$

Dalam lampiran Undang-Undang Nomor 3 Tahun 1950 dijelaskan bahwa urusan agraria (tanah) meliputi: ${ }^{30}$

1. Penerimaan penyerahan hak "eigendom" atas tanah "eigendom" kepada negeri (medebewind).

2. Penyerahan tanah negara (feheersoverdracht) kepada jawatan-jawatan atau kementerian lain atau kepada daerah autonom (medebewind).

3. Pemberian ijin membalik nama hak " eigendom" dan "opstal" atas tanah, jika salah satu fihak atau keduanya masuk golongan bangsa asing (medebewind).

4. Pengawasan pekerjaan daerah autonom dibawahnya tentang agraria (sebagian ada yang medebewind).

Ada beberapa peraturan daerah yang mengatur pengelolaan di bidang pertanahan, diantaranya Peraturan Daerah Nomor 4 Tahun 1954, Peraturan Daerah Nomor 5 Tahun 1954, Peraturan Daerah Nomor 10 Tahun 1954, Peraturan Daerah Nomor 11 Tahun 1954 dan Peraturan Daerah Nomor 12 Tahun 1954. Terbitnya peraturan daerah tersebut maka kewenangan pengelolaan pertanahan yang semula menjadi kewenangan kasultanan dan kadipaten beralih menjadi kewenangan Pemerintah DIY, termasuk didalamnya pengelolaan tanah kasultanan yang dikenal dengan tanah Sultan Ground (SG) dan Pakualaman Ground (PG).

Tahun 2012 Undang-Undang Mengenai Keistimewaan DIY telah disahkan dan diterbitkan, yaitu Undang-Undang Nomor 13 Tahun 2012. Terkait pertanahan diatur dalam Pasal 32 Ayat (1) dan (2) yang menyebutkan:

(1) Dalam penyelenggaraan kewenangan pertanahan sebagaimana dimaksud dalam Pasal 7 Ayat (2) huruf d, kasultanan dan kadipaten dengan undang-undang ini dinyatakan sebagai badan hukum.

(2) Kasultanan sebagai badan hukum merupakan subjek hak yang mempunyai hak milik atas tanah kasultanan penetapan kasultanan menjadi badan hukum yang dapat menjadi subyek hak milik atas tanah tentunya akan membawa konsekuensi perubahan dalam pengelolaan tanah kasultanan, karena sebelumnya hubungan antara kasultanan dengan tanah adalah hubungan antara suatu lembaga pemerintahan (lembaga publik/lembaga penguasa) dengan wilayah yang dikuasainya sehingga pengelolaan tanah oleh kasultanan pada saat itu dilakukan dalam rangka menjalankan tugas pemerintahan.

Terkait proses demokratisasi di DIY masih terus berlangsung sesuai dinamika politik lokal yang menekankan substansi demokrasi (musyawarah untuk mencapai mufakat), sehingga sampai dengan saat ini belum melaksanakan pemilihan gubernur dan pemilihan wakil gubernur. Hal itu disebabkan DIY melalui sistem penetapan secara langsung, karena posisi Gubernur DIY merupakan wakil pemerintah pusat (bertanggung jawab langsung

${ }^{29}$ Baskoro dan Sunaryo, Catatan Perjalanan Keistimewaan Yogya Merunut Sejarah, Mencermati Perubahan, Menggagas Masa Depan, (Yogyakarta: Pustaka Pelajar, 2010), hlm. 72.

${ }^{30}$ Kristiyani dkk, Himpunan Peraturan Peraturan Daerah DIl Perihal Tanah, (Yogyakarta: tanpa penerbit, 1981), hlm. 6. 
kepada Presiden) seumpama camat melakukan tugas pembantuan (tidak desentralisasi) dengan walikota, bupati, yang dipilih secara langsung oleh rakyat.

Menurut penulis, implementasi desentralisasi asimetris di DIY belum terlaksana secara maksimal dikarenakan masih terdapat beberapa amanat UUK DIY yang belum diterapkan dalam hal:

Pertama, dalam hal penyerapan dana keistimewaan yang diatur dalam Peraturan Gubernur Daerah Istimewa Yogyakarta Nomor 37 Tahun 2014 tentang Pengelolaan Dana Keistimewaan, belum diimplementasikan dengan baik dikarenakan penyaluran anggaran pada tingkat Kuasa Pengguna Anggaran (KPA) berefek pada keterlambatan transfer anggaran dan mundurnya agenda-agenda yang telah direncanakan oleh masing-masing KPA disebabkan belum turun dari pemerintah daerah.

Kedua,mengenai penetapan gubernur dan wakili gubernur dalam Pasal 18 Ayat (4) Undang-Undang Dasar Negara Kesatuan Republik Indonesia Tahun 1945 menyatakan bahwa "gubernur, bupati dan walikota masingmasing sebagai kepala pemerintahan daerah provinsi, kabupaten dan kota dipilih secara demokrasi". Namun, dalam praktik keistimewaan DIY berbeda berdasarkan Pasal 18B Ayat (1), yang menyatakan bahwa "negara mengakui dan menghormati satuan-satuan pemerintahan daerah yang bersifat khusus atau bersifat istimewa yang diatur dengan undang-undang".

Berdasarkan UUK DIY tersebut pada tahun 2015 dikeluarkanlah Peraturan Daerah Istimewa (Perdais) Yogyakarta Nomor 2 Tahun 2015 tentang Tata Cara Pengisian Jabatan, Pelantikan, Kedudukan, Tugas dan Kewenangan Gubernur dan Wakil Gubernur, hal ini sesuai amanat Undang-Undang Nomor 13
Tahun 2012 tentang Keistimewaan Daerah Istimewa Yogyakarta.Menurut Pasal 25 Ayat (1) dan Ayat (2) Undang-Undang Nomor 13 Tahun 2012 bahwa masa jabatan Sultan Hamengku Buwono sebagai gubernur dan Adipati Paku Alam sebagai wakil gubernur terhitung 5 (lima) tahun semenjak pelantikan dan pemangku jabatan sebagai gubernur dan wakil gubernur tidak terikat pada ketentuan 2 (dua) kali periodisasi sebagaimana yang diatur dalam undang-undang pemerintahan daerah.

Penetapan Perdais tersebut sudah sesuai amanat UUK DIY agar tidak terjadi kegaduhan yang mana pada tahun 2017 Sultan Hamengku Buwono $X$ ingin melepaskan tahtanya sebagai gubernur maupun melanjutkan periode berikutnya untuk menjadi gubernur sekaligus Raja Yogyakarta.

Ketiga, dalam hal kebudayaan belumlah optimal dikarenakan amanat dari Pasal 31 Ayat (2) Undang-Undang Nomor 13 Tahun 2012 tentang Keistimewaan Daerah Istimewa Yogyakarta mengenai pengaturan dalam bentuk Perdais yang khusus mengatur tentang kebudayaan. Namun ada Perdais yang mengatur tentang pembentukan dinas kebudayaan, yang diatur dalam Perdais Yogyakarta Nomor 6 Tahun 1998 tentang Pembentukan Dinas Kebudayaan Provinsi Daerah Istimewa Yogyakarta, yang ditetapkan pada tanggal 25 Mei 1998 dan diundangkan pada tanggal 12 Oktober 1998.

Tetapi, dalam tahap implementasi UUK DIY, Pemerintah DIY dan pihak Dewan Perwakilan Rakyat Daerah (DPRD) DIY belum menyelesaikan Perdais tentang Kebudayaan. PadahalPasal 31 Ayat (2) mengamanatkan pengaturan mengenai kebudayaan dituangkan dalam Perdais. DIY baru menetapkan Peraturan Gubernur DIY Nomor 95 Tahun 2015 tentang Pembentukan, Susunan Organisasi, Uraian 
Tugas dan Fungsi Serta Tata Kerja Unit Pelayanan Teknis Pada Dinas Kebudayaan. Peraturan Gubernur tersebut ditetapkan pada tanggal 25 Oktober 2015.

Keempat, mengenai tata ruang cukup optimal pada tataran implementasi karena Perdais telah selesai. Hal ini sesuai amanat Pasal 35 Undang-Undang Nomor 13 Tahun 2012 tentang Keistimewaan Daerah Istimewa Yogyakarta, yaitu Perdais Yogyakarta Nomor 2 Tahun 2010 tentang Rencana Tata Ruang Wilayah Provinsi Daerah Istimewa Yogyakarta Tahun 2009-2029.

Penelitian yang dilakukan oleh Suryanto menjelaskan terkait keistimewaan tata ruang Yogyakarta, mengenai penataan ruang sesuai Undang-Undang Nomor 13 Tahun 2012 tentang Keistimewaan Daerah Istimewa Yogyakarta tidak cukup sebagai acuan dalam pengaturan keistimewaan tata ruang Kota Yogyakarta. Konsep keistimewaan tata ruang Kota Yogyakarta tidak jelas. Padahal, pertimbangan dasar dari keistimewaan Yogyakarta berdasarkan akar sejarah dan budaya. ${ }^{31}$

Menurut penulis seharusnya pembangunan tata ruang, baik kota maupun kabupaten di DIY merupakan warisan yang berharga di Yogyakarta haruslah mencerminkan kebudayaan DIY yang bersifat istimewa. Keraton Yogyakarta memiliki karakter khusus yang berbeda dari daerah lain. Bangunan Keraton Yogyakarta merupakan sumber dari planologi Yogyakarta yang penuh dengan simbol hidup dan kehidupan manusia. Bangunan itu melambangkan hubungan Tuhan dan ciptaanNya baik secara metafisis, spiritual, maupun secara antropologi filsafat". ${ }^{32}$ Bukan hanya berdasarkan nilai ekonomi semata, namun juga berdasarkan atas acuan sejarah dan budaya. Apabila pembangunan bersegikan pada kebudayaan dan sejarah pastilah hal ini menjadikan nilai tambah DIY yang tidak dimiliki oleh daerah lain.

Kelima,mengenai bidang pertanahan. Kebijakan pertanahan di DIY dalam implementasi UUK DIY ternyata tidak sesuai harapan masyarakat terkait keistimewaan dan peraturan perundang-undangan yang berlaku. Wacana ketiadaan tanah negara di DIY dan/ atau tidak berlakunya Undang-Undang Pokok Agraria (UUPA) di DIY merupakan sebuah hal menarik.

Berdasarkan Pasal 43 Undang-Undang Nomor 13 Tahun 2012 tentang Keistimewaan DIY pada intinya memerintahkan agar Sultan selaku gubernur dan Pakualaman selaku wakil gubernur melakukan inventarisasi dan pendaftaran tanah SG dan PG kepada Badan Pertanahan Nasional (BPN). Namun, sampai saat ini belum ada diterima oleh BPN mengenai hal tersebut. Menurut penulis UUK DIY tidak bisa menjamin kepemilikan tanah warga Yogyakarta, karena dalam UUK DIY tidak menjelaskan luasan dan peruntukan tanah SG dan PG.

\section{Kesimpulan}

Kewenangan keistimewaan DIY belum dapat dilakukan secara maksimal dikarenakan baru dapat diselesaikannya tiga perdais mengenai pengisian jabatan gubernur dan wakil gubernur DIY, tentang rencana tata ruang wilayah dan tentang kelembagaan. Namun,

\footnotetext{
${ }^{31} \mathrm{https}$ ://ugm.ac.id, Keistimewaan Tata Ruang Kota Yogyakarta Makin Ditinggalkan, diakses pada tanggal 09 Desember 2015.

${ }^{32}$ Arief Aulia Rachman, Akulturasi Islam dan Budaya Masyarakat Yogyakarta: Sebuah Kajian Literatur, Jurnal Indo Islamicka Sekolah Pascasarja UIN Syarif Hidayatullah Jakarta, Volume 1, Nomor 2, 2012, hlm. 164.
} 
pada saat penelitian ini dilakukan ada 2 (dua) Raperdais yang belum selesai, yaitu tentang kebudayaan dan pertanahan.

\section{Saran}

Sebaiknya di DIY dilakukan pemisahan jabatan sebagai kepala pemerintahan (gubernur) dengan jabatan sebagai raja (sultan), agar tidak tumpang tindih dan campur aduk antara kewenangan gubenur dengan kewenangan raja.

\section{Referensi}

Arief Aulia Rachman. Akulturasi Islam dan Budaya Masyarakat Yogyakarta: Sebuah Kajian Literatur, Jurnal Indo Islamicka Sekolah Pascasarja UIN Syarif Hidayatullah Jakarta. Volume 1. Nomor 2. Tahun 2012.

Bagir Manan. 2004. Menyongsong Fajar Otonomi Daerah. Yogyakarta: Pusat Studi Hukum UII.

Baharudin. Desain Daerah Khusus/Istimewa Dalam Sistem Negara Kesatuan Republik Indonesia Menurut Konstitusi. Jurnal Masalah-Masalah Hukum. Jilid 45. Nomor 2. April 2016.

Baskoro dan Sunaryo. 2010. Catatan Perjalanan Keistimewaan Yogya Merunut Sejarah, Mencermati Perubahan, Menggagas Masa Depan. Yogyakarta: Pustaka Pelajar.

Budi Agustono. 2005. Otonomi Daerah dan Dinamika Politik Lokal: Studi Kasus di Kabupaten Deli Serdang, Sumatera Utara dalam Desentralisasi Globalisasi dan Demokrasi Lokal. Jakarta: LP3ES.

Dharma Setyawan Salam. 2002. Otonomi Daerah Dalam Perspektif Lingkungan,
Nilai, dan Sumber Daya. Jakarta: Djambatan.

Djohermansyah Djohan. Desentralisasi Asimetris Aceh. Jurnal Sekretariat RI. Nomor 15. Desember 2014.

Donald K. Emmerson. 2001. Indonesia Beyond Soeharto: Negara, Ekonomi, Masyarakat, Transisi. Jakarta: PT Gramedia.

Hanif. 2003. Teori dan Praktek Pemerintahan. Jogjakarta: Grafindo.

Hanif Nurcholis. 2005. Teori dan Praktik Pemerintahan dan Otonomi Daerah. Jakarta: PT Grasindo.

Irawan Soejito. 1984. Hubungan Pemerintah Pusat dan Pemerintah Daerah. Jakarta: Bina Aksara.

Jawahir Thontowi. 2007. Apa Istimewa Yogyakarta?. Yogyakarta: Pustaka Fahim.

Kristiyani dkk 1981. Himpunan Peraturan Peraturan Daerah DIl Perihal Tanah. Yogyakarta: tanpa penerbit.

Sakir dan Dyah Mutiarin. Kebijakan Anggaran Dana Keistimewaan Daerah Istimewa Yogyakara. Jurnal Ilmu Pemerintahan \& Kebijakan Publik. Volume 2. Nomor 3. Oktober 2015.

Sedarmayanti. 2004. Good Governance (Kepemerintahan yang Baik), Cetakan Kedua. Bandung: Mandar Maju.

Siswanto Sunarno. 2006. Hukum Pemerintahan Daerah di Indonesia. Jakarta: Sinar Grafik.

Soerjono Soekamto. 1983. Faktor-Faktor yang Mempengaruhi Penegakan Hukum. Jakarta: Rajawali Pers.

Syamsuddin Haris. 2005.Desentralisasi dan Otonomi Daerah: Desentralisasi, Demokratisasi dan Akuntabilitas 
Pemerintahan Daerah. Jakarta: LIPI Press.

Sukirno dan Dwi Kuncahyo. Penerapan Desentralisasi Asimetris Dalam Penyelenggaraan Urusan Keistimewaan Daerah Istimewa Yogyakarta Sebagai Basis Otonomi Bagi Terwujudnya Kesejahteraan Rakyat. Jurnal Cakrawala Hukum. Volume XI. Nomor 1. Tahun 2015.

Tim ICCE UIN Jakarta. 2003. Pendidikan Kewargaan (Civic Education)
Demokrasi, Hak Asasi Manusia dan Masyarakat Madani. Jakarta: Prenada Media.

Wahyudi Kumorotomo dan Ambar Widaningrum, 2010. Reformasi Aparatur Negara Ditinjau Kembali. Yogyakarta: Gava Media.

Wibowo Eddi. 2004.Hukum dan Kebijakan Publik. Yogyakarta: Yayasan Pembaruan Administrasi Publik Indonesia.

Wojowasito S. 1975.Kamus Umum InggrisIndonesia. Jakarta: Cypress. 